\title{
Why do South African companies not report more environmental information when managers are so positive about this kind of reporting?
}

\author{
CJ de Villiers \\ Department of Financial Management \\ University of Pretoria
}

\begin{abstract}
Previous research has highlighted a contradiction in regard to environmental reporting in South Africa. Managers, who can influence decisions regarding disclosure, express the view that more environmental reporting is needed, yet very little such reporting is done.

A questionnaire was sent to every company listed on the Johannesburg Stock Exchange (JSE) with the request that the financial director should complete it. The questionnaire set out to establish whether managers are still as positive about environmental reporting as reported in previous research findings and, furthermore, to determine the reasons for the dearth of environmental reporting.

Managers are still as positive as before about environmental reporting. The reasons for not reporting range from the contention that data is not available, that there are no legal requirements and that there is no demand for the data to the contention that it is not applicable to the particular industry and that costs exceed benefits. Most respondents do not regard the fear of liability to be a very important reason for non-disclosure.

The most important reason for non-disclosure is that there is no legal requirement in respect of disclosure. This reason, together with the positive attitude of directors towards environmental reporting in general and towards reporting on a compulsory basis in particular, makes a strong case for the introduction of legislation in this regard. The introduction of legislation could be achieved by amending the Fourth Schedule of the Companies' Act or the introduction by The South African Institute of Chartered Accountants (SAICA) of a statement of Generally Accepted Accounting Practice (GAAP) on environmental disclosure.
\end{abstract}

continued

Meditari Accountancy Research Vol. $112003: 11-23$ 


\section{Key words}

Environmental reporting

Environmental accounting

Environmental disclosure

\section{Trefwoorde}

Omgewingsverslaglewering

Omgewingsrekeningkunde

Omgewingsopenbaarmaking

\section{Introduction}

There is an apparent discrepancy between the attitudes of South African managers towards environmental disclosure and the actual environmental disclosure that listed companies do.

South African managers are reportedly extremely positive about environmental disclosure (De Villiers and Vorster 1995; De Villiers 1998). The "managers" surveyed in these studies were directors of companies that are listed on the Johannesburg Stock Exchange (JSE). They were therefore in a position to influence decisions on disclosure. Non-response bias was sufficiently addressed in the 1998 survey to render the results reliable. The results of the 1998 and 1995 surveys were compared and the differences were found to be not statistically significant (De Villiers 1998:154-155 and 162).

Examples of the extremely positive responses of the managers are provided below (De Villiers 1998:159):

\section{Positive*}

An overview of environmental risks/impacts $\quad 89 \%$ Environmental policy $\quad 95 \%$ Measurable environmental targets $\quad 63 \%$ Performance on environmental targets $68 \%$

* The responses were given on a five-point scale of which the two top categories were "agree" and "strongly agree". The percentages of the respondents that chose these two top categories are reported here.

Actual environmental reporting lags behind these positive attitudes. For example, De Villiers and Barnard (2000) reported the following actual disclosure in the 1999 annual reports of the Financial Mail Top 100 industrial companies and the mining companies listed on the JSE:

\begin{tabular}{|l|c|c|}
\hline & Top 100 & Mining \\
\hline Environmental risks/impacts & $24 \%$ & $48 \%$ \\
Environmental policy/mission & $31 \%$ & $52 \%$ \\
Measurable environmental targets & $11 \%$ & $29 \%$ \\
Environmental targets achieved or not achieved & $22 \%$ & $42 \%$ \\
\hline
\end{tabular}

The two studies used almost identical categories (in the four instances above) and actual reporting fell far short of positive attitudes. The research question that is addressed in this paper is why this situation prevails. 
Corporate environmental reporting and disclosure are perceived to be good for society as a whole for the reasons outlined in the next section of this paper. If the impediments to companies' environmental disclosure could be determined, they could possibly be removed and the positive attitudes toward disclosure converted into actual disclosure.

A questionnaire was sent to the financial directors of all the JSE-listed companies. They were asked about their attitudes regarding environmental reporting and disclosure in order to determine whether they are still as positive as a few years ago when the previous surveys were done. They were also asked for the reasons why the companies did not disclose (or did not disclose more) environmental information.

Following this introduction is a discussion on why corporate environmental reporting is regarded to be in the interest of society as a whole. Additional background information on related South African and international studies also follows. Thereafter the method of the research is described, followed by sections on the results, a summary, implications and limitations.

\section{Corporate environmental reporting is good for society}

All companies use natural resources. Many of these resources, like clean air, are not paid for directly. They are referred to as "externalities", because the cost is not reflected on the companies' income statements. However, society does pay, sometimes directly, for example when the quality of air is compromised and it results in respiratory disease and medical costs. Sometimes society pays indirectly, for example when aesthetic quality is affected and a reduced quality of life results from pollution.

If companies are not held accountable for their use of natural resources, these resources could be abused to the detriment of society. Outsiders do not have access to company records and procedures. Therefore the only way in which accountability can be achieved is for companies to give an account of how they have impacted on the natural environment, how they plan to ameliorate their effects in the future and whether in the recent past they have managed to achieve the goals that they had set earlier. Companies that give account in this manner will be open to criticism from society and the criticism will oblige them to improve. This effect will reduce the direct and indirect costs to society that are described in the preceding paragraph.

The notion of accountability that is described above is well developed in the literature on social accounting (see for example Gray et al 1995; Gray et al 1996; Burrit and Welch 1997; Gray et al 1997; Mathews 1997).

It can therefore be argued that corporate environmental reporting is good for society and that academic accountants should do all in their power to promote it. The aim of promoting a form of accounting that is good for society is in perfect

Meditari Accountancy Research Vol. $112003: 11-23$ 
harmony with the general aim of research for academic accountants (Kinney 2003). There is a constant search for better items and forms of disclosure that can ensure transparency and, therefore, the efficient allocation of resources in the economy (Kinney 2003).

\section{Additional background}

A recent paper by Solomon and Lewis (2002) addresses the incentives and disincentives for corporate environmental reporting. In general terms, corporations see environmental reporting as reflecting positively on their corporate image as well as being a socially responsible and ethical activity. The major disincentives are the sensitivity of the information and the lack of a legal requirement in respect of disclosure (Solomon and Lewis 2002).

Research on the views of managers and executives on environmental reporting, both internationally (Woodward et al 2001; Adams 2002; Buhr 2002) and in South Africa (De Villiers 1999), generally do not focus specifically on the disincentives for or the impediments to environmental reporting.

Naturally, papers that investigate the likelihood that companies will report environmental information and relate it to other publicly known information (Cormier and Gordon 2001; Freedman and Stagliano 2002; Patten 2002) cannot comment on management's views in general and on disincentives and impediments in particular.

There are empirical studies (Tilt 2001; Tilt and Symes 1999) that suggest that corporate environmental reporting is done in an unsystematic, sometimes haphazard fashion, while the format and the items disclosed are changed to suit management's agenda.

\section{The questionnaire (including the method applied)}

The questionnaire is reproduced in appendix A and covers the first five questions of the survey by De Villiers (1998) to establish attitudes towards environmental accounting. Questions regarding specific types of environmental disclosure (such as risks and impacts) were left out in favour of the question relating to the impediments to reporting. The possible impediments to environmental reporting mentioned by Gray (1993) were used to prompt respondents. Space was provided for them to state additional impediments.

The questionnaire was sent to the 615 companies listed on the JSE in June 2000 and addressed to the financial director. There were $72(12 \%)$ usable responses.

Non-response bias was addressed by analysing the representation by sector of the respondents versus the universe.

There appears to be a reasonable representation of all sectors with the exception of the mining companies. The largest industry group, namely industrial 
companies, is well represented. The industrial company group is the only one that has sufficient respondents to influence the overall finding substantially, but the response rate for this industry group is very close to the average response rate. This analysis appears to indicate an absence of non-responses from a particular industry group or of an undue dominance of responses by another industry group.

\section{The results}

The results of the questions that were designed to establish whether managers are still as positive about environmental reporting as before are given below together with comparable results from the De Villiers (1998) study:

\begin{tabular}{|c|c|c|}
\hline & Current study & 1998 study \\
\hline Question & Avg. (\% Positive) & Avg. (\% Positive) \\
\hline More environmental disclosure (voluntary) & $3.5 \quad(67)$ & $4.2 \quad(89)$ \\
\hline More environmental disclosure (compulsory) & $3.6 \quad(69)$ & $3.5 \quad(58)$ \\
\hline More environmental disclosure - financial & $3.8 \quad(72)$ & $3.8 \quad(74)$ \\
\hline $\begin{array}{l}\text { More environmental disclosure - non- } \\
\text { financial }\end{array}$ & $3.8 \quad(76)$ & $3.9 \quad(89)$ \\
\hline $\begin{array}{l}\text { Environmental disclosure should be in: } \\
\text { annual reports }\end{array}$ & $4.2 \quad$ (95) & $3.9 \quad$ (84) \\
\hline separate environmental report & $2.3 \quad(18)$ & $\mathrm{N} / \mathrm{a}$ \\
\hline local community brochure & $2.7 \quad(32)$ & $\mathrm{N} / \mathrm{a}$ \\
\hline web-based format & $3.5(66)$ & $\mathrm{N} / \mathrm{a}$ \\
\hline
\end{tabular}

When the results of the current study are compared with that of the De Villiers (1998) study, it becomes clear that managers are generally as positive now as they were before, with some interesting differences. Fewer managers are in favour of voluntary environmental disclosure and more are in favour of compulsory disclosure. Could this trend be the emergence of a more pragmatic view, which concedes that environmental reporting is inevitable, and, if so, the playing field should be levelled by ensuring that all companies are obliged to report?

More managers than before are also in favour of including environmental information in the annual report. Web-based environmental information also appears to be a popular alternative. Both these options would be fairly cost effective. This consideration could be part of the attraction that these options have for the financial directors that make up the respondents.

Directors, who are in a position to influence decisions on disclosure, were positive about environmental disclosure from 1995 (De Villiers and Vorster 1995) through 1998 (De Villiers 1998) to 2000 (current study). Why then was corporate environmental reporting at the relatively low levels that were reported by De Villiers and Barnard (2000) and quoted in the introduction above?

Meditari Accountancy Research Vol. 112003 : 11-23 
The responses to the section of the questionnaire relating to this question appear below:

\begin{tabular}{|l|rr|rr|}
\hline \multicolumn{1}{|c|}{$\begin{array}{c}\text { Impediments } \\
\text { (Ranking given in brackets) }\end{array}$} & Average & $\begin{array}{c}\text { \% answering important } \\
\text { reason or very } \\
\text { important reason }\end{array}$ \\
\hline No need or motivation to disclose & 2.9 & $(2)$ & 64 & $(3)$ \\
A "wait and see" attitude & 2.3 & & 45 & \\
Costs exceed benefits & 2.7 & $(6)$ & 57 & $(6)$ \\
Relevant data not available & 2.9 & $(2)$ & 69 & $(1)$ \\
Secrecy & 1.9 & & 27 & \\
Competitive disadvantage & 1.9 & & 27 & \\
No demand for the information & 2.8 & $(5)$ & 62 & $(4)$ \\
No legal requirement for information & 3.0 & $(1)$ & 66 & $(2)$ \\
Never thought of environmental reporting & 2.0 & & 39 & \\
Other disclosure priorities & 2.6 & $(7)$ & 56 & $(7)$ \\
Others aren't doing it & 2.5 & $(9)$ & 48 & $(9)$ \\
Fear of liability & 2.1 & & 34 & \\
Not applicable to our industry & 2.9 & $(2)$ & 56 & $(7)$ \\
Do not know what/how to report & 2.6 & $(7)$ & 60 & $(5)$ \\
\hline
\end{tabular}

Only one respondent offered a reason for non-disclosure other than the ones provided in the questionnaire. It was obviously not one of the popular reasons.

The most popular reasons are highlighted by the "ranking" provided above. The most popular reasons for non-disclosure are either that there is no legal requirement in respect of the information or that the relevant data is not available, depending on whether the average or the percentage column above is regard as being more relevant. However, the latter reason is not very informative. Imagine a situation in which a financial director does not disclose fixed assets, because the data is not available. The data will be available, because the item has to be disclosed and measures are put into operation to accumulate the data. If the disclosure of environmental information were a statutory requirement or if management deemed it to be sufficiently important, measures would be instituted to collect the information, collate it and disclose it. Therefore, the most important reason cited is that there is no legal requirement for the disclosure of environmental information. Solomon and Lewis (2002) also found a lack of a legal requirement to be one of the most important disincentives for disclosure.

The most popular reasons are highlighted by the "ranking" provided above. The most popular reasons for non-disclosure are either that there is no legal requirement in respect of the information or that the relevant data is not available, depending on whether the average or the percentage column above is regard as being more relevant. However, the latter reason is not very informative. Imagine a situation in which a financial director does not disclose fixed assets, because the data is not available. The data will be available, because the 
item has to be disclosed and measures are put into operation to accumulate the data. If the disclosure of environmental information were a statutory requirement or if management deemed it to be sufficiently important, measures would be instituted to collect the information, collate it and disclose it. Therefore, the most important reason cited is that there is no legal requirement for the disclosure of environmental information. Solomon and Lewis (2002) also found a lack of a legal requirement to be one of the most important disincentives for disclosure.

The following are the reasons cited as being next in importance: There is no need or motivation to disclose; there is no demand for the information; and it is not applicable to our industry. Once again, these reasons are not very helpful. All three these reasons could be disputed by various interest groups that do not include management. For example, companies in almost all industries use energy, occupy buildings, operate vehicles, use water and make daily decisions that influence the natural environment. Supermarkets stock items that may not be environmentally friendly and banks lend money to companies that have less than exemplary environmental records. An indication that these ideas are not without merit is that ten leading international banks have recently agreed to incorporate social and environmental issues in their loan criteria (Star Business Report 2003).

The next most popular reason given by respondents is that they do not know what or how to report. Simply talking to corporate stakeholders could easily remove this impediment. The King Report on Corporate Governance recommends this course of action.

Financial directors also state that the cost of environmental disclosure exceeds the benefit derived from it. This point could be argued in the narrow sense of cost versus benefit to the company in the manner that the respondents have probably interpreted it. However, if it is argued that the benefits to the whole of society are more relevant to this particular analysis, the benefits could well outweigh the costs.

Finally, to complete the list of the nine most cited and popular reasons for not disclosing environmental information, respondents also indicated other disclosure priorities and the fact that other companies are not disclosing. This ninth reason is related to the first (no legal requirement) as well as to the very positive attitude (69\% in favour, see above) of respondents regarding compulsory environmental disclosure. Legislation would make environmental disclosure compulsory and the other companies would also disclose the information.

\section{Summary, implications and limitations}

The most important reason cited by the financial directors of companies that are listed on the Johannesburg Stock Exchange why companies do not disclose environmental information, although the financial directors themselves are very positive about such disclosure, is that there is no legal requirement for them to

Meditari Accountancy Research Vol. $112003: 11-23$ 
do so. This fact, together with the fact that $69 \%$ of the financial directors are in favour of more comprehensive disclosure of environmental matters on a compulsory basis, provides a compelling case for legislation. The King II Report (Institute of Directors 2002:121) also recommend this course of action by stating that: "It is recommended that companies be given legislative incentives to improve performance, encourage best practice and promote compliance with environmental corporate governance." The legal requirement of compulsory environmental disclosure by companies can be achieved by amending the Fourth Schedule of the Companies' Act or by the South African Institute of Chartered Accountants (SAICA) issuing an Environmental Disclosure statement of Generally Accepted Accounting Practice (GAAP). Directors of companies apparently want to disclose environmental issues, but they want their competitors to do the same. The only way in which this objective can be achieved is to make disclosure compulsory. Disclosure of this kind would benefit society as a whole, as argued above.

The major limitations of this study are the relatively low response rate and concerns regarding non-response bias. The question that arises is whether the $12 \%$ response rate can be construed to represent all financial directors of JSElisted companies. Industry groups are well represented among the respondents. Furthermore, the first part of the questionnaire yielded responses very similar to the responses in the previous study. In the previous study (De Villiers 1998), non-response bias was adequately addressed and completely removed as a concern. Although all doubt has not been removed, for the above-mentioned two reasons, the results of the current study should be taken seriously.

\section{Appendix A}

The Financial Director

\section{Dear Sir}

We are currently conducting research on the reasons for environmental reporting and the impediments to it. We need your assistance to ensure reliable results, irrespective of whether you are positive or negative about the issues.

Please complete the enclosed questionnaire and mail or fax it back to us. It should only take approximately 10 minutes of your time. The relevant mail and fax numbers appear below.

I can assure you that the questionnaire have been thoroughly tested and the results will be used in the strictest of confidence for the purpose of answering important research questions only.

Yours truly,

Fax no: XXXX

Or mail to: $\mathrm{XXXX}$ 


\section{STRICTLY CONFIDENTIAL \\ QUESTIONNAIRE ON ENVIRONMENTAL REPORTING}

No:

My official designation (job title) is:

A Willingness to support more comprehensive environmental disclosure

Please indicate whether you personally agree/ disagree with the following statements.

1 More comprehensive disclosure of environmental matters is needed on a voluntary basis (the company decides for itself).

2 More comprehensive disclosure of environmental matters is needed on a compulsory basis (the company is forced to report, but so is its competitors).

3 More comprehensive environmental disclosure of a financial nature is needed.

4 More comprehensive environmental disclosure of a nonfinancial nature is needed, such as descriptive information or information in physical quantitative measures.

5 Companies should disclose environmental information in: The annual report

A separate environmental report Local community brochure Web-based format Other ways (specify)

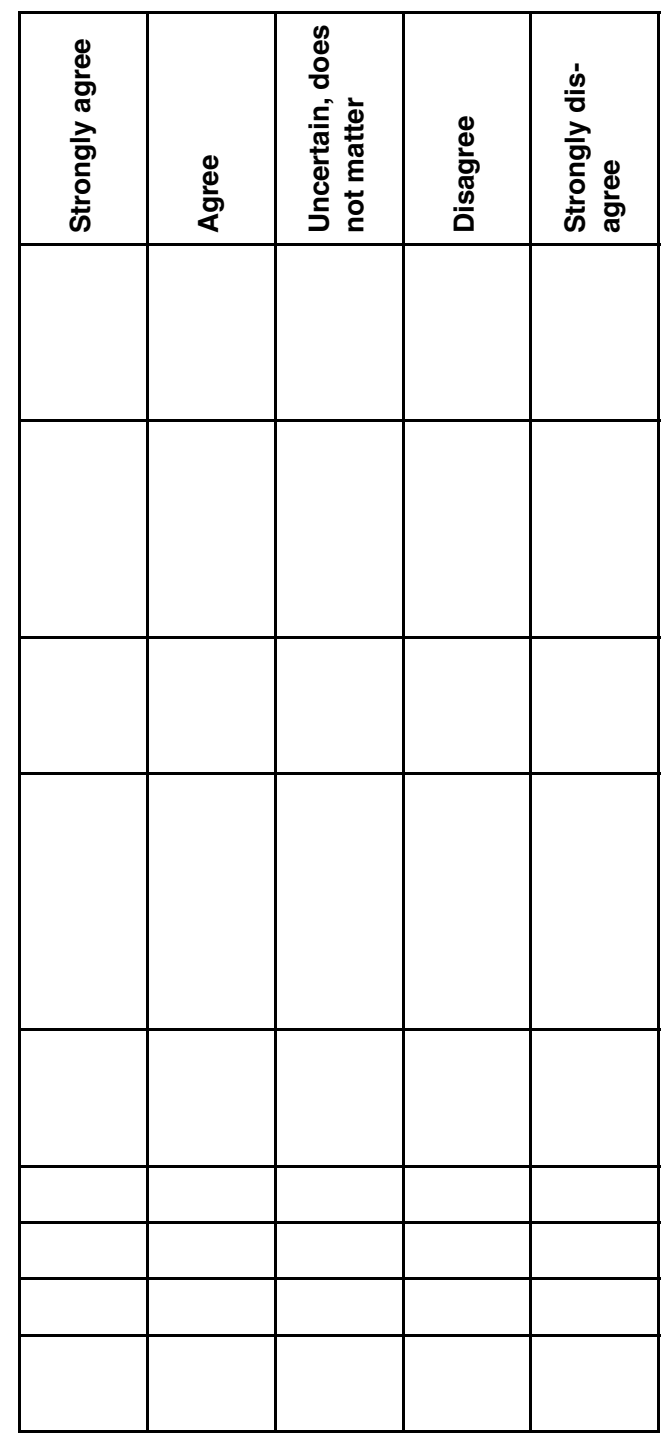




\section{PLEASE ANSWER THE QUESTIONS ON THE REVERSE SIDE TOO.}

If you would like a copy of the survey results, please state your name and contact details

Name:

Position:

Company:

Postal address:

Code:

E-mail address:

\section{B Impediments to the disclosure of environmental matters}

Please indicate your perception of the importance of the following reasons, for not reporting (or not reporting more) on environmental matters, for your company.

Please answer both sections, i.e. not reporting and not reporting more.

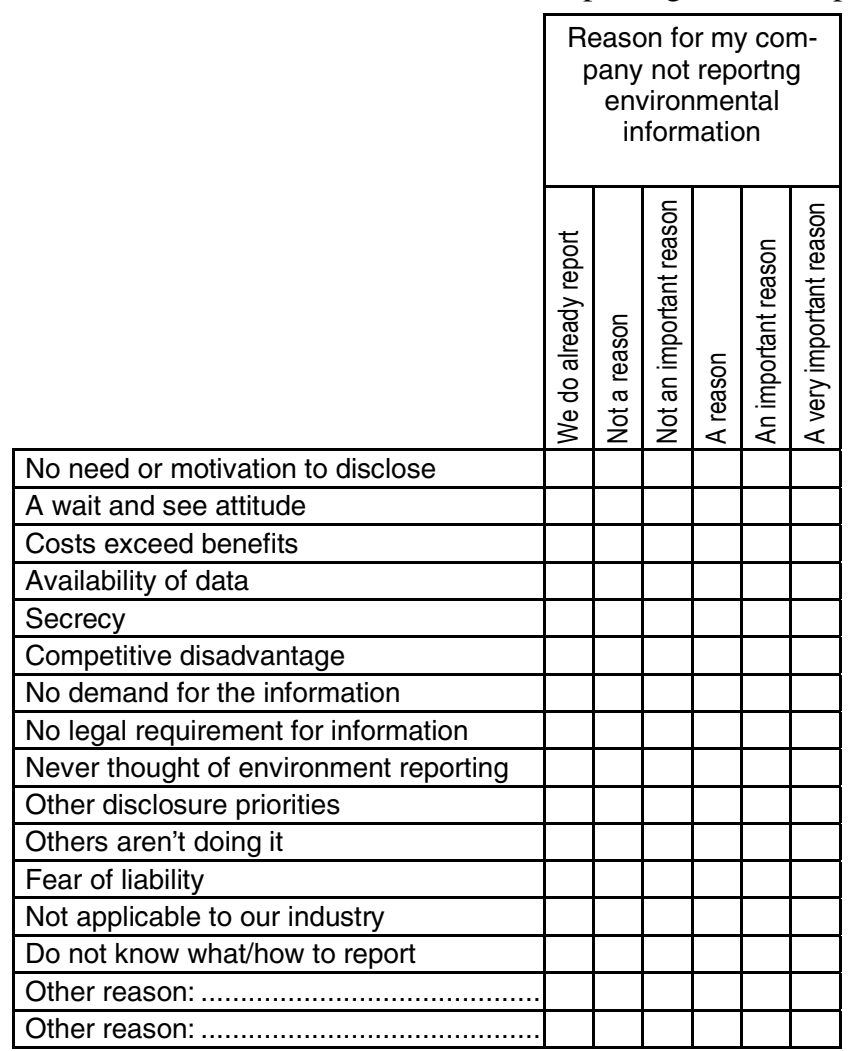

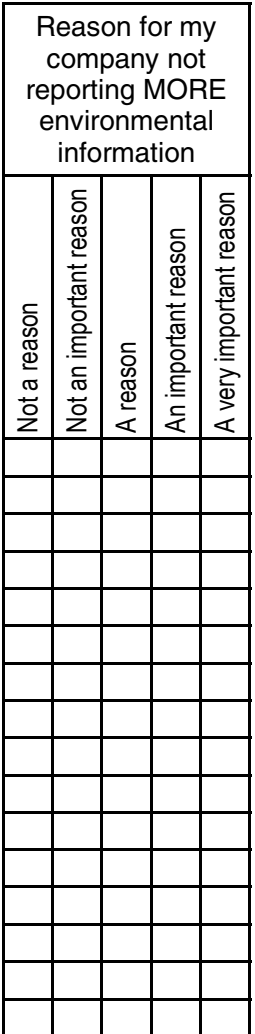


Please indicate where your company report environmental information:

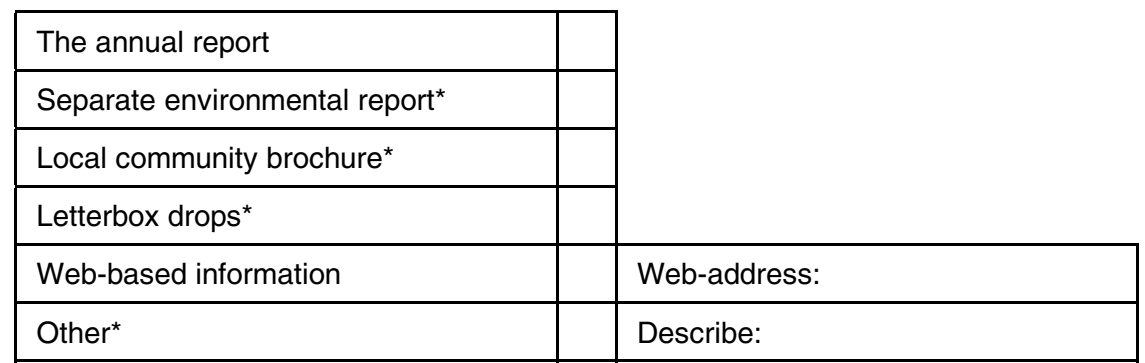

\section{Bibliography}

Adams, C. 2002. Internal organizational factors influencing corporate social and ethical reporting, Accounting, Auditing and Accountability Journal, Vol. 15, No. 2, pp.223-250.

Buhr, N. 2002. A structuration view on the initiation of environmental reports, Critical Perspectives on Accounting, Vol. 13, No. 1, pp.17-38.

Burrit, R.L. and Welch, S. 1997. Accountability for environmental performance of the Australian Commonwealth public sector, Accounting, Auditing and Accountability Journal, Vol. 10, No. 4, pp.532-561.

Cormier, D. and Gordon, I.M. 2001. An examination of social and environmental reporting strategies, Accounting, Auditing and Accountability Journal, Vol. 14, No. 5, pp.587-616.

De Villiers, C.J. 1998. The Willingness of South Africans to Support More Green Reporting, South African Journal of Economic and Management Sciences, NS, Vol. 1, No. 1, pp.145-167.

De Villiers, C.J. 1999. The decision by management to disclose environmental information: A research note based on interviews, Meditari Accountancy Research, Vol. 7, pp.33-48. 
De Villiers, C.J. and Barnard, P. 2000. Environmental Reporting in South Africa from 1994 to 1999: A research note, Meditari Accountancy Research, Vol. 8, pp.15-23.

De Villiers, C.J. and Vorster, Q. 1995. More Corporate Environmental Reporting in South Africa?, Meditari Accountancy Research, Vol. 3, pp.44-66.

Freedman, M. and Stagliano, A.J. 2002. Environmental disclosure by companies involved in initial public offerings, Accounting, Auditing and Accountability Journal, Vol. 15, No. 1, pp.94-195.

Gray, R.H. 1993. Accounting for the Environment, London: Paul Chapman Publishing.

Gray, R., Kouhy, R. and Lavers, S. 1995. Corporate social and environmental reporting: A review of the literature and a longitudinal study of UK disclosure, Accounting, Auditing and Accountability Journal, Vol. 8, No. 2, pp.47-77.

Gray, R., Owen, D. and Adams, C. 1996. Accounting and Accountability: Changes and challenges in corporate social and environmental reporting, Prentice Hall, London.

Gray, R., Dey, C., Owen, D., Evans, R. and Zadek, S. 1997. Struggling with the praxis of social accounting: Stakeholders, accountability, audits and procedures, Accounting, Auditing and Accountability Journal, Vol. 10, No. 3, pp.325-364.

Institute of Directors. 2002. King report on corporate governance for South Africa - 2002, Institute of Directors, Parktown.

Kinney, W.R. 2003. New Accounting Scholars - Does it matter what we teach them?, Issues in Accounting Education, Vol. 18, No. 1, pp.37-47.

Mathews, M.R. 1997. Twenty-five years of social and environmental accounting research: Is there a silver jubilee to celebrate?, Accounting, Auditing and Accountability Journal, Vol. 10, No. 4, pp.481-531.

Patten, D.M. 2002. Media exposure, public policy pressure and environmental disclosure: An examination of the impact of TRI data availability, Accounting Forum, Vol. 26, No. 2, pp.152-171.

Solomon, A. and Lewis, L. 2002. Incentives and disincentives for corporate environmental disclosure, Business Strategy and the Environment, Vol. 11, No. 3, pp154-169.

Star Business Report. 2003. Top Banks Agree to Socially Responsible Financing, Star Business Report, 5 June, p.8.

Tilt, C.A. and Symes, C. 1999. Environmental disclosure in Australian mining companies: Environmental conscience or commercial reality?, Accounting Forum, Vol. 23, No. 2, pp.137-154. 
Tilt, C.A. 2001. The content and disclosure of Australian environmental policies, Accounting, Auditing and Accountability Journal, Vol. 14, No. 2, pp.190212.

Woodward, D., Edwards, P. and Birkin, F. 2001. Some evidence on executives' views on corporate social responsibility, British Accounting Review, Vol. 33, No. 3, pp.357-397. 